\title{
A new species of Goodenia (Goodeniaceae) from Nocoleche Nature Reserve, Far Western Plains, New South Wales
}

\author{
Belinda J. Pellow ${ }^{1}$ and John L. Porter ${ }^{2}$ \\ ${ }^{1}$ Janet Cosh Herbarium, School of Biological Sciences, University of Wollongong, Northfield's \\ Avenue, Wollongong, NSW 2522, Australia.email: bpellow@ uow.edu.au \\ 2 Waterbird and River Ecology Unit, NSW Department of Environment and Conservation, \\ P.O. Box 1967, Hurstville, NSW 2220, Australia
}

\begin{abstract}
Goodenia nocoleche was cultivated in sediment collected from a freshwater temporary wetland in Nocoleche Nature Reserve. Here it is newly described and illustrated with additional notes on its ecology.
\end{abstract}

\section{Introduction}

A species of Goodenia was cultivated from sediments collected in Nocoleche Nature Reserve during a study on seed banks of arid zone wetlands of the Paroo-Bulloo River region of New South Wales (Porter 2002). It represents a new species. An ephemeral herb, it has also been observed growing in its natural habitat at Pied Stilt Swamp and a clay pan on the Wanaaring-Hungerford Rd. (29 $\left.28^{\prime} 00^{\prime \prime S}, 144^{\circ} 24^{\prime} 00^{\prime \prime E}\right)$.

\section{Methods}

Non-dormant seed banks of wetlands were sampled in June and September 1997 following the methods of Brock et al. (1994) to collect sediment cores. Sixty sediment samples were collected randomly from each wetland, $($ depth $=2.5 \mathrm{~cm}$, surface area $=$ $\left.0.012 \mathrm{~m}^{2}\right)$. Sediment samples were placed in shallow plastic trays for drying, then submerged in water $(60 \mathrm{~cm}$ depth) to stimulate germination.

Examination of the cultivated specimens revealed a yellow corolla with ovules and seeds numerous in two rows on either side of the septum, characters which placed them in the section Porphyranthus of the genus Goodenia. However, the small flowers with calyx lobes which are just short of or equalling the corolla lobes distinguish it from others in this section. 


\section{Taxonomy}

\section{Goodenia nocoleche B. Pellow \& J. L. Porter sp. nov.}

Herba ephemera a speciebus duabus artissime cognatis (G. lamprosperma atque G. paniculata) corolla parva $5-5.5 \mathrm{~mm}$ longa, lobis calycis $4-6 \mathrm{~mm}$ longis corollam subaequantibus distinguenda.

Holotype: NEW SOUTH WALES: cultivated from seed collected $15 \mathrm{~km} \mathrm{~S}$ of Wanaaring, Pied Stilt Swamp, Nocoleche Nature Reserve, J. Porter, 29 Mar 2000 (NSW 458574).

Ephemeral amphibious herb to $40 \mathrm{~cm}$ high, vegetative parts glabrous. Basal leaves with floating lamina $20-40 \mathrm{~mm}$ long, 7-14 mm wide, thin, glossy green above, flat, lanceolate, margins undulate and minutely toothed, apex acute with tooth. Petioles elongated to $60 \mathrm{~cm}$ long, much longer than lamina, lengthening with water depth. Cauline leaves present at base of flowering stem $10-40 \mathrm{~mm}$ long, $2-3 \mathrm{~mm}$ wide. Flowers in racemes. Bracts longer towards base of inflorescence, linear and sometimes resembling leaves, 10-40 $\mathrm{mm}$ long. Bracteoles linear, 8-10 mm long, 0.6-1 $\mathrm{mm}$ wide, with minute simple and glandular hairs; bracteoles occasionally producing axillary buds which extend into new inflorescence branches. Pedicels $2-5 \mathrm{~mm}$ long without articulation. Floral tube 3-5 mm long with minute simple and glandular hairs. Calyx lobes linear, 4-6 mm long, $0.8-1 \mathrm{~mm}$ wide, numbering 5 or sometimes 6 , attaching in top $1 / 3$ of floral tube and covered with minute simple and glandular hairs. Corolla yellow, 5-5.5 mm long, lobe tips often tinged with pink or purple; glandular and simple hairs present externally, glabrous internally; no enations observed; anterior pocket obscure; abaxial lobes $2 \mathrm{~mm}$ long with wings approximately $0.5 \mathrm{~mm}$ wide; adaxial lobes $2.5 \mathrm{~mm}$ long with wings approximately $0.5 \mathrm{~mm}$ wide. Staminal filaments $1.8-2.0 \mathrm{~mm}$ long, anthers $0.5-0.8 \mathrm{~mm}$ long. Ovary with numerous ovules in 2 rows on either side of the septum; septum almost as long as the ovary. Style $2-2.5 \mathrm{~mm}$ long with scattered long simple hairs; indusium 1-1.5 mm long, 1-1.3 mm wide, purplish in colour, hairs present on adaxial rim, abaxial rim without hairs. Fruit pale, obconical, 5-6.5 mm long, 2-3 mm wide, hispid with short simple and glandular hairs. Seed $1 \mathrm{~mm}$ long, $2.5 \mathrm{~mm}$ wide, light brown, glossy, reticulation faint, winged. Figures 1 and 2.

Selected specimens examined: New South Wales: Far North Western Plains: Cultivated from sediment collected from Pied Stilt Swamp, Nocoleche Nature Reserve. $15 \mathrm{~km}$ south of Wanaaring. 2952'18"S, 14405'12"E. 100m alt. J.L. Porter JLP 255, 29 Mar 2000 (8107-WOLL, 8108-WOLL, 8111-WOLL, 8113-WOLL).

Distribution: This species has been recorded in the seed banks of five wetlands in the Paroo-Bulloo River region. It was common (mean density $1,511 \mathrm{~m}^{-2} \pm 189 \mathrm{se}$ ) in the seed bank of one freshwater temporary wetland, Pied Stilt Swamp and uncommon (mean density $<15 \mathrm{~m}^{-2}$ ) in Momba Swamp (29 $52^{\prime} 45^{\prime \prime S} 144^{\circ} 06^{\prime} 30^{\prime \prime E}$ ), Waitchie Lake $\left(30^{\circ} 10^{\prime} 00^{\prime \prime S} 144^{\circ} 01^{\prime} 15^{\prime \prime E}\right)$, Lake Altibouka $\left(29^{\circ} 49^{\prime} 00^{\prime \prime S} 142^{\circ} 45^{\prime} 00^{\prime \prime E}\right)$ and Lake Numalla $\left(28^{\circ} 44^{\prime} 00^{\prime \prime S} 144^{\circ} 19^{\prime} 00^{\prime \prime E}\right)$ (Fig. 3). It has also been recorded from field observations growing in Pied Stilt Swamp and another unnamed wetland c. $70 \mathrm{~km}$ north of Wanaaring. Three of these locations (Pied Stilt, Momba and Numalla) are within conservation reserves on the Paroo river floodplain (Fig. 3).

Habitat: Goodenia nocoleche was most abundant in temporary freshwater wetlands. Pied Stilt and Momba Swamps are small (22 and 61 ha), shallow (1.3 and $1.4 \mathrm{~m}$ ) 




Fig. 1. Goodenia nocoleche B. Pellow \& J.L. Porter. a, habit; b, flower; c, fruit. Scale bar: a = $80 \mathrm{~mm}$, $\mathrm{b}=6 \mathrm{~mm} ; \mathrm{c}=6 \mathrm{~mm}$. 


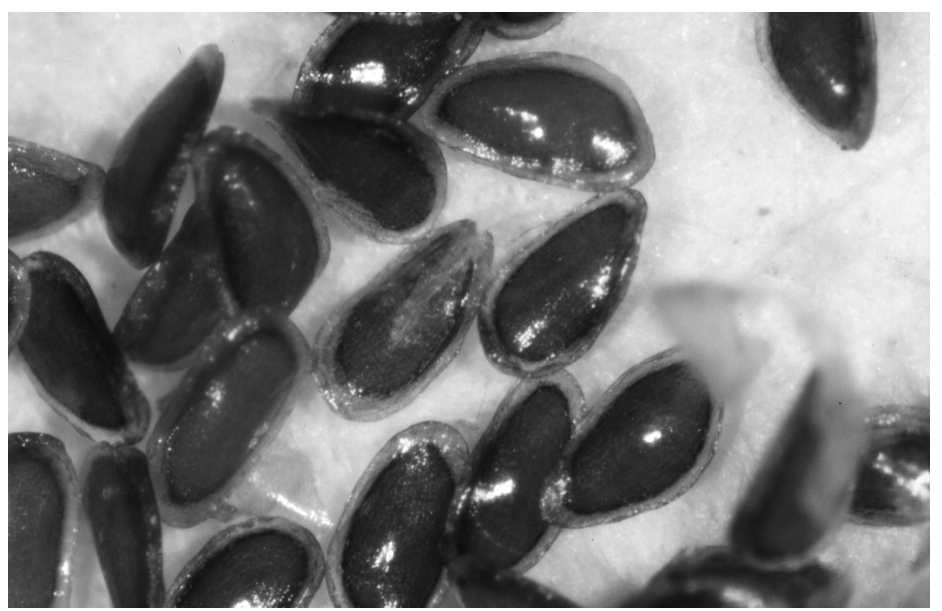

Fig. 2. Seeds of Goodenia nocoleche B. Pellow \& J.L. Porter.

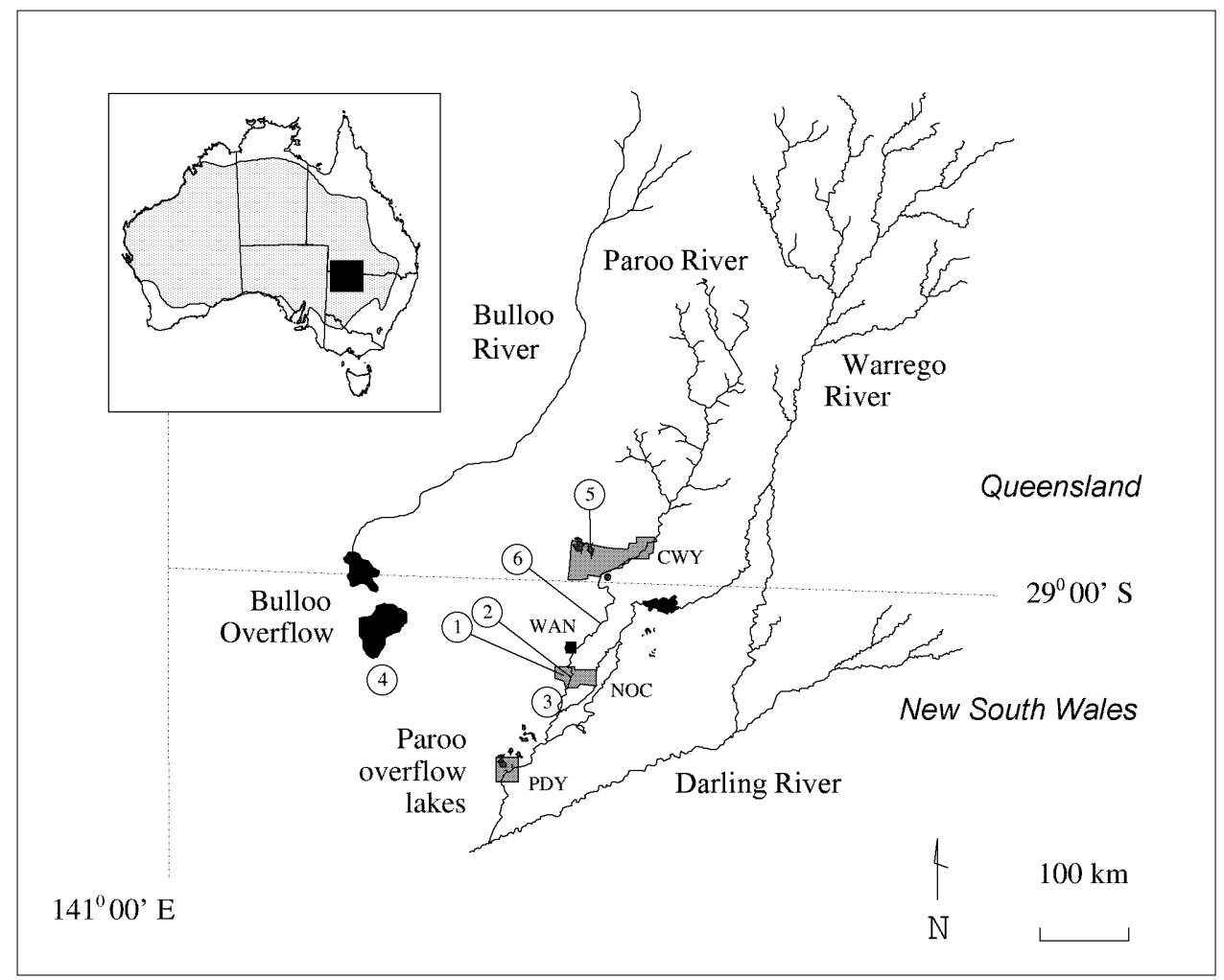

Fig. 3. Occurrence of Goodenia nocoleche (inset, dark square) in Australia's arid zone $(<500 \mathrm{~mm}$ annual average rainfall, stippled) and five wetland seed banks sampled: Pied Stilt Swamp (1), Momba Swamp (2), Waitchie Lake (3), Lake Altibouka (4), Lake Numalla (5). Unnamed claypan wetland where Goodenia nocoleche was observed growing (6). Conservation reserves on the Paroo River are Currawinya National Park (CWY), Nocoleche Nature Reserve (NOC) and Paroo Darling National Park (PDY). Town (dark square) is Wanaaring (WAN). 
'claypan' basins with uneven substrates, caused partly by expansion and contraction of grey or brown cracking clays. They fill predominantly from local rainfall and only connect to the Paroo floodplain via Momba Creek after heavy local rain. From 1990-2000 the swamps held water for a total of 17 and 22 months respectively. Their water is turbid after flooding, clearing gradually during the drying phase, especially in Pied Stilt Swamp. Plant communities in these temporary wetlands undergo considerable changes during erratic filling and drying cycles, as aquatic plants, sedges, annual grasses, herbs and forbs become abundant during and after inundation, before declining again. During prolonged dry periods ground cover may be virtually absent and many species remain hidden below the surface as propagules in seed banks or underground storage organs.

Vegetation around the swamp margins consists of a narrow band of trees, mostly Eucalyptus largiflorens and E. populnea subsp. bimbil. Within the swamps trees are absent, and perennial shrub understories are absent or sparse with occasional grasses. After flooding sedges are common at the margins, and in open water floating-leaved submergent or partially emergent species may occur. (Kingsford \& Porter 1999).

Ecology: Goodenia nocoleche can germinate and grow in standing water up to $0.6 \mathrm{~m}$ deep, with floating leaves on greatly extended petioles (Fig. 4), similar in appearance to Potomogeton octandrus. As water recedes inflorescences emerge and grow rapidly. The plants die back rapidly as sediments dry completely. Goodenia nocoleche has been observed growing in Pied Stilt Swamp during several flood events (December 1998, 2000) and appears to be a summer annual needing inundation in shallow temporary freshwater wetlands to stimulate a germination response from the persistent seed bank, followed by partial drying to initiate flowering. These observations are supported by the behaviour of the species in cultivation. Ability to initiate vegetative growth and

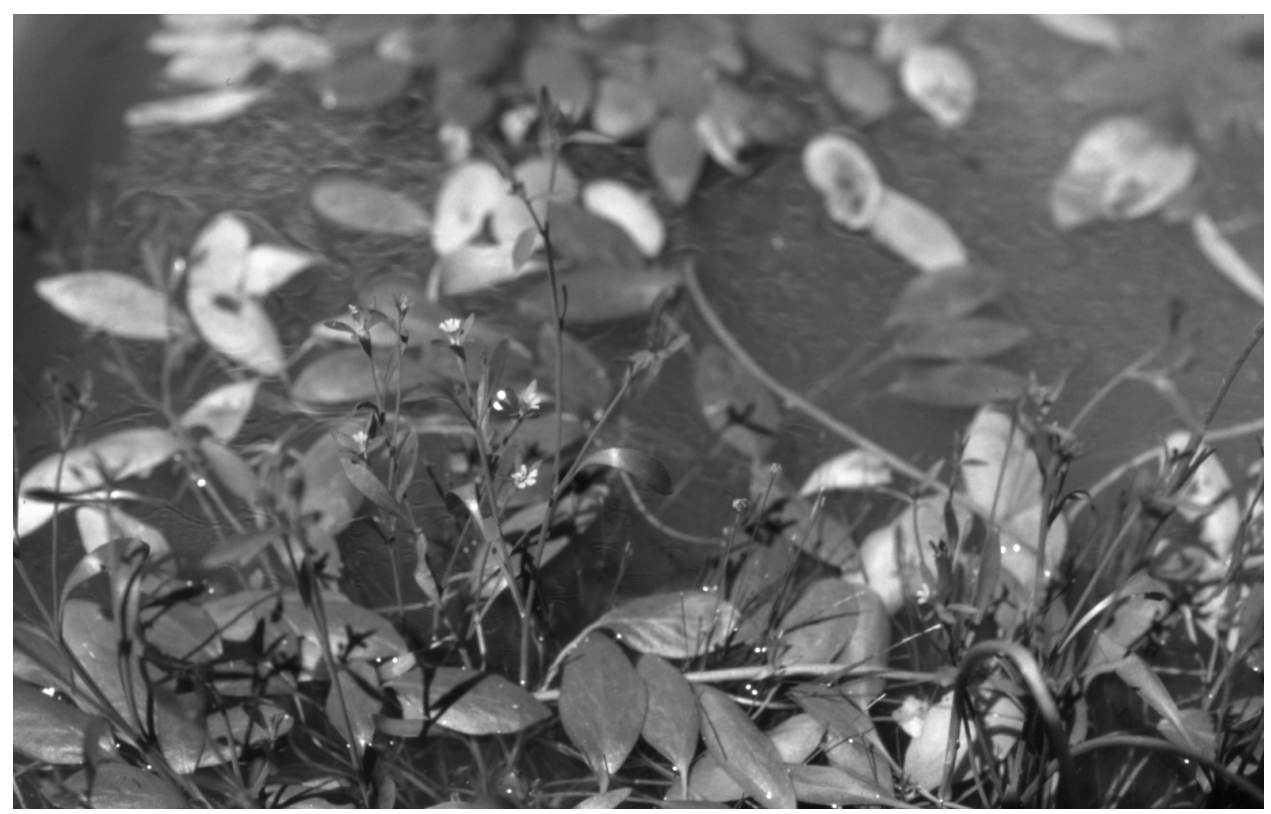

Fig. 4. Goodenia nocoleche B. Pellow \& J.L. Porter in cultivation. 
form floating leaves early in the drying cycle of temporary wetlands may confer some advantage compared to other low growing amphibious species that also colonise the exposed sediments of drying wetlands (e.g. Mimulus repens, Ranunculus sessiliflorus var. pilulifer, Pratia darlingensis). In functional group terms, Goodenia nocoleche is an 'amphibious fluctuation-responder' because it alters it growth pattern or morphology in response to the presence or absence of water (Brock \& Casanova 1997). Amphibious and aquatic plants in arid zone wetlands are generally poorly known, because many species are short-lived and access to these remote areas is difficult when water is present. Potential threats to this species include invasive weeds that are spread by water such as Pistia stratiotes and Xanthium occidentale and alterations to flow regimes of rivers and floodplains.

Etymology: the epithet is taken from the name of the Nature Reserve where this species was found. It is derived from an aboriginal word meaning 'place of many waterholes'

Notes: In his description of two new species of Goodenia from the Northern Territory, Albrecht (2002) defines bracteoles according to Briggs and Johnson (1979) calling the structures opposite or sub-opposite bracteoles due to the presence of buds in their axils. We have chosen to keep the term bracteole for these occurrences, according to Carolin $(1990,1992)$. Although buds do occur within the axis of some bracteoles of the inflorescence the majority of the bracteoles do not exhibit them.

A specimen of Goodenia lamprosperma (NSW 460174) collected in a semi-aquatic environment exhibits similar leaf morphology to that of G. nocoleche. Other specimens of G. lamprosperma not recorded as growing in semi-aquatic situations exhibited different leaf morphology. The characters of extended leaf petiole, larger lamina and reduced stem length may be related to the semi-aquatic habitat. Goodenia nocoleche has been observed in the field with terrestrial leaves immediately prior to flowering in situations where the water levels have receded but no specimens have been collected for examination. Seedlings of G. nocoleche (8110-WOLL) show a number of delicate, lanceolate leaves $12 \mathrm{~mm}$ long and $2 \mathrm{~mm}$ wide which are produced prior to the development of the basal leaves with extended petioles.

\section{Acknowledgments}

We would like to thank the staff at the National Herbarium of New South Wales, in particular Joy Everett for her comments on the manuscript. Peter Wilson provided the Latin diagnosis and Catherine Wardrop prepared the botanical illustrations. Roger Carolin provided advice and encouragement.

\section{References}

Albrecht DE (2002) New species and notes on central Australian Goodenia (Goodeniaceae). Nuytsia 15: 1-9.

Briggs BG \& Johnson LAS (1979) Evolution in the Myrtaceae-evidence from inflorescence structure. Proceedings of the Linnean Society of New South Wales 102: 157-256.

Brock MA \& Casanova MT (1997) Plant life at edge of wetlands: ecological responses to wetting and drying patterns. In N Klomp \& LI Klomp (eds) Frontiers in ecology: building the links. (Elsevier Science: Oxford, UK) 
Brock MA, Theodore K \& O’Donnell L (1994) Seed-bank methods for Australian wetlands. Aquatic Botany 45: 483-493.

Carolin RC (1990) Nomenclatural notes and new taxa in the genus Goodenia (Goodeniaceae). Telopea 3: 517-570.

Carolin RC (1992) Goodenia. Pp. 147-281 in AS George (ed.) Flora of Australia, vol. 35. (Australian Government Publishing Service: Canberra)

Kingsford RT \& Porter J (1999) Wetlands and waterbirds of the Paroo and Warrego Rivers. Pp. 23-50 in RT Kingsford (ed.) A free-flowing River: The Ecology of the Paroo River (NSW NPWS: Sydney Australia)

Porter J (2002) Effects of salinity, turbidity and water regime on arid zone wetland seed banks. Verh. Inernat. Verein. Limnol. 28: 1486-1471.

Manuscript received 1 September 2004, accepted 2 May 2005 